University of Nebraska - Lincoln

DigitalCommons@University of Nebraska - Lincoln

USDA National Wildlife Research Center - Staff Publications
U.S. Department of Agriculture: Animal and Plant Health Inspection Service

2018

\title{
Ecology of the Small Indian Mongoose (Herpestes auropunctatus) in North America
}

\author{
Are R. Berentsen \\ USDA National Wildlife Research Center, Are.R.Berentsen@aphis.usda.gov \\ William C. Pitt \\ Smithsonian Institute \\ Robert T. Sugihara \\ USDA/APHIS/WS/National Wildlife Research Center
}

Follow this and additional works at: https://digitalcommons.unl.edu/icwdm_usdanwrc

Part of the Life Sciences Commons

Berentsen, Are R.; Pitt, William C.; and Sugihara, Robert T., "Ecology of the Small Indian Mongoose (Herpestes auropunctatus) in North America" (2018). USDA National Wildlife Research Center - Staff Publications. 2034.

https://digitalcommons.unl.edu/icwdm_usdanwrc/2034

This Article is brought to you for free and open access by the U.S. Department of Agriculture: Animal and Plant Health Inspection Service at DigitalCommons@University of Nebraska - Lincoln. It has been accepted for inclusion in USDA National Wildlife Research Center - Staff Publications by an authorized administrator of DigitalCommons@University of Nebraska - Lincoln. 


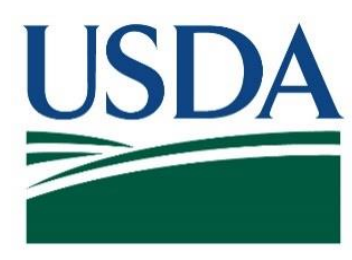

U.S. Department of Agriculture

U.S. Government Publication

Animal and Plant Health Inspection Service

Wildlife Services

Berentsen, A.R., W.C. Pitt, and R.T. Sugihara. 2018. Ecology of the small Indian mongoose (Herpestes auropunctatus) in North America. pgs. 251-267. In: W.C. Pitt, J.C. Beasley, and G.W Witmer, editors. Ecology and Management of terrestrial vertebrate invasive species in the United States. CRC Press, Boca Raton, FL. 403 pp.

Are R. Berentsen, USDA APHIS National Wildlife Research Center

William C. Pitt, Smithsonian Institute

Robert T. Sugihara, USDA APHIS NWRC, Hilo, Hawaii 


\title{
12 Ecology of the Small Indian Mongoose (Herpestes auropunctatus) in North America
}

\author{
Are R. Berentsen, William C. Pitt, \\ and Robert T. Sugihara
}

\section{CONTENTS}

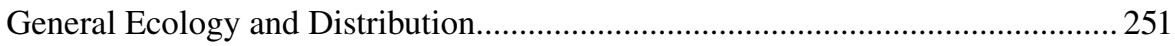

Intentional Introductions to the Caribbean and Hawaii ...........................................253

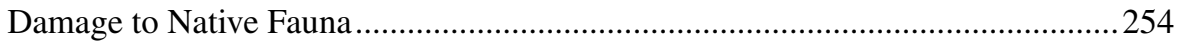

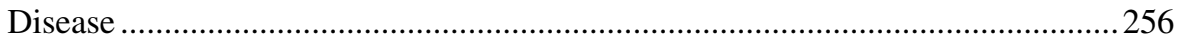

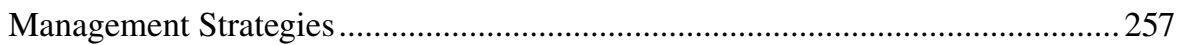

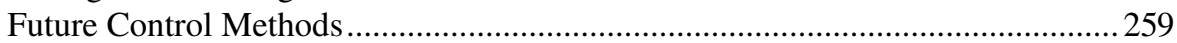

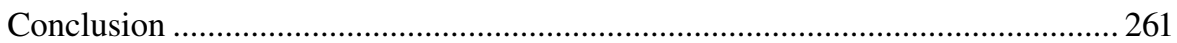

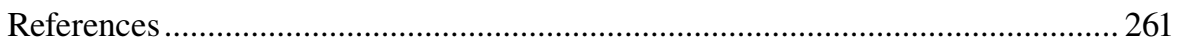

\section{GENERAL ECOLOGY AND DISTRIBUTION}

The small Indian mongoose (Herpestes auropunctatus) is a diurnal opportunistic omnivore native to parts of the Middle East, India, and Asia (Corbet and Hill 1992; Lekagul and McNeely 1977; Veron et al. 2007). Much of what is known about the species comes from records of populations where they were introduced to control rodents on sugarcane plantations (predominantly the Caribbean Islands and Hawaii) rather than their native range (Horst et al. 2001). In published research, the introduced mongoose is alternately, and often synonymously, identified as $H$. auropunctatus or $H$. javanicus. However, research by Veron et al. (2007) suggests that $H$. auropunctatus and $H$. javanicus are distinct taxa with unique biogeographic ranges: $H$. auropunctatus from the Middle East to Myanmar and H. javanicus from Myanmar and east, throughout Southeast Asia. Myanmar represents the eastern and western limits of $H$. auropunctatus and $H$. javanicus, respectively (Veron et al. 2007). Given documentation by Espeut (1882) that the mongoose's introduced to the Caribbean, and later Hawaii, originated from Calcutta, India, it is now generally accepted that the mongoose species introduced to North America is $H$. auropunctatus.

Small Indian mongooses were introduced to several regions worldwide to reduce rodent damage to sugar plantations and in some cases for viper control (e.g., habu 
[Trimeresurus flavovirids] and horned viper [Vipera ammodytes] [Barun et al. 2011]; fer-de- lance [Bothrops lanceolatus, B. atrox] [Barun et al. 2011; Myers 1931]; St. Lucia Lancehead pit viper [B. caribbaeus] [Des Vœux 1903]). These introductions took place in Croatia (Barun et al. 2008, 2011), Fiji (Gorman 1975), Okinawa (Yamada 2002), Australia (failed attempt, reviewed by Peacock and Abbott 2010), Trinidad (Urich 1914), portions of coastal South America (Nellis 1989), throughout the Caribbean (Hoagland et al. 1989), and Hawaii (Doty 1945; Baldwin et al. 1952).

Mongooses are slender with short legs, an elongated muzzle, and short ears (Nellis 1989). The dental formula is similar to the basic formula for carnivores: $\mathrm{I} 3 / 3, \mathrm{C} 1 / 1$, $\mathrm{P} 4 / 4, \mathrm{M} 2 / 2$. Mongooses exhibit sexual dimorphism: females reach sexual maturity at approximately $305 \mathrm{~g}$ with an average adult weight of $434 \mathrm{~g}$, whereas males typically reach sexual maturity at approximately $395 \mathrm{~g}$ and average $650 \mathrm{~g}$ as adults (Nellis and Everard 1983). However, males weighing over $1000 \mathrm{~g}$ have been recorded in food-rich habitats (Berentsen, unpublished data). The term "auropunctatus" means "golden points" and refers to the speckled, gold-colored tips of the pelage. Mongooses are terrestrial and diurnal (Baldwin et al. 1952) and occupy terrestrial burrows, including spaces beneath large boulders and likely spaces around roots and logs as well as natural cracks in lava substrates in Hawaii (Pimentel 1955a; Hinton and Dunn 1967). They are opportunistic generalists and feed on a variety of prey items, including insects, lizards, rats, crustaceans, human refuse, seeds, birds, bird eggs, vegetable matter, and carrion (Williams 1918; Spencer 1950; Baldwin et al. 1952; Wolcott 1953; Kami 1964; Vilella and Zwank 1993; Vilella 1998; Horst et al. 2001; Pitt et al. 2015). Mongooses are largely considered a solitary species but will congregate around locally abundant food resources and discarded animal carcasses (Pitt et al. 2015). Throughout their native range, mongooses are found in open, forested, and scrub habitats (Shekhar 2003). Pimentel (1955a) suggested that because mongooses are poor climbers they avoid forest habitats, but in many Caribbean regions they have expanded their range to include broad expanses of subtropical dry forest and subtropical rainforest (Vilella 1998; Horst et al. 2001). In addition, their introduced range includes agricultural land and urban areas (Spencer 1950; Baldwin et al. 1952). In Asia, the species can be found in elevations up to $2100 \mathrm{~m}$ (Simberloff et al. 2000) and has been recorded at elevations of up to $3000 \mathrm{~m}$ on Hawaii (Baldwin et al. 1952).

Mongooses are capable of breeding year round, although two to three birth peaks tend to occur throughout the year in an apparent correlation with day length (Nellis and Everard 1983), as has been suggested in Fiji (Gorman 1976). Gestation is approximately seven weeks (Asdell 1964), and young remain with the mother for four to six months (Hays and Conant 2007). Typical litter size is two to four pups (Asdell 1964; Nellis and Everard 1983; Coblentz and Coblentz 1985a). Precise life expectancy is unknown as traditional aging techniques relying on tooth wear are inconsistent as a result of differing regional diets and a paucity of known-age reference specimens. Pearson and Baldwin (1953) established relative age criteria based on tooth irruption in mongooses on Hawaii and documented mongooses up to 40 months of age, but did not have known-age samples as a reference. Personnel from the U.S. Department of Agriculture (USDA)/Wildlife Services captured and uniquely numbered mongooses via subcutaneous injection of a passive integrated transponder (PIT tag) on Hawaii that were recaptured four and a half years later during a subsequent study 
(R. Sugihara, pers. obs.). In Puerto Rico, Horst et al. (2001) used PIT tagging of known-aged animals and documented ages of at least 81 months.

Population density and home range estimates throughout the Caribbean and Hawaii are highly variable and can differ among studies depending on experimental design and analysis methods. Mongoose population density in the Caribbean ranges from 0.19 to 9.0 mongooses/ha (Pimentel 1955a,b; Hoagland et al. 1989; Corn and Conroy 1998; Vilella 1998; Horst et al. 2001; Quinn and Whisson 2005; Hudson 2010; Johnson et al. 2016). Horst et al. (2001) suggested that mongoose population density in Puerto Rico was lower in grasslands than semiwooded regions, Vilella (1998) found relatively low densities in montane humid and rainforest regions, but Guzmán-Colón and Roloff (2014) found no correlation between habitat type and population density. Population densities in Hawaii are estimated at 0.04 mongoose/ha in lowland wetlands to 3.0/ha in moist forests (Stone et al. 1994). Population densities on Hawaii are reported to be higher at elevations between 1515 and $2060 \mathrm{~m}$ above sea level (Duffy 2007).

Mongoose home range estimates in the Caribbean range from 1.0 to over 50 ha (Berentsen, unpublished data; Nellis 1989; Quinn and Whisson 2005; Edwards 2006) and may vary with season. Males tend to have larger home ranges than females (Berentsen, unpublished data; Quinn and Whisson 2005). Mongoose home range estimates in Hawaii are comparable to those found in the Caribbean and range from 6.0 to over 70 ha (Hays 1999; Pitt et al. 2015). Male mongooses tend to have larger home ranges and longer point-to-point travel distances than females (Hays and Conant 2003; Pitt et al. 2015).

\section{INTENTIONAL INTRODUCTIONS TO THE CARIBBEAN AND HAWAII}

Small Indian mongooses have been introduced to over 64 islands worldwide (Barun et al. 2011). However, in this section, we restrict our discussion to sugarcaneproducing islands of the Caribbean and Hawaii.

As early as 1814, it was suggested that the mongoose be introduced to control rats (Lunan 1814). The first recorded introduction of mongooses to the Caribbean region took place around 1870 when an unknown number of mongooses originating from India were introduced to the island of Trinidad (Urich 1914). Little documentation exists regarding its outcome, but Urich (1914) suggested a second introduction took place in 1898, which implies the initial attempt in 1870 was unsuccessful. By 1870, approximately one-fifth of some sugar plantation harvests in Jamaica were lost to rat damage, resulting in significant financial losses to plantation owners (Lewis 1953). Numerous attempts at importing mongooses into Jamaica for rodent control were made circa 1872, but all failed as the mongooses were obtained from captive colonies in the United Kingdom (Lewis 1953). However, on February 13, 1872, nine mongooses (four males and five females) were introduced to the Spring Garden Estate, Jamaica, directly from Calcutta, India, by W. B. Espeut (Espeut 1882). Initial success in suppressing rat populations in Jamaica resulted in the export of mongooses to several other Caribbean Islands, including Cuba and Puerto Rico (Espeut 1882). To date, the small Indian mongoose has become established on at least 29 islands throughout the Caribbean, with most introductions having occurred prior to 1900 (Horst et al. 2001). 
Following the initial success of rat control in the Caribbean (West Indies), the small Indian mongoose was introduced several times to Hawaii in 1883 (Doty 1945; Baldwin et al. 1952), and mongooses currently are found on the Hawaiian Islands of Hawaii, Maui, Molokai, and Oahu (Baldwin et al. 1952; Hays and Conant 2007). Anecdotal reports describe early introduction attempts onto sugar plantations on Kauai, likely during the late 1800s. These reports describe crate(s) of mongooses shipped from Hawaii to Kauai where, upon being bitten by a mongoose in one of the crates, a dockworker allegedly disposed of the crates by throwing them off the pier. While these reports have circulated among families who worked on the Kauai sugar plantations, they have not been substantiated. Sporadic sightings occurred on Kauai in 1976 when a lactating female on Kauai was killed by an automobile (Tomich 1986). More recent reports suggest mongooses persist on Kauai, with two being trapped (USDA, unpublished data), but it is unclear whether an extensive breeding population has become established. Credible sightings have been reported (Menard et al. 2013) but large-scale trapping is prohibited, making population estimation problematic.

Interisland travel within the Hawaiian Islands, islands in the Caribbean, as well as between the Caribbean and the Florida Keys has raised concern about unintentional introduction of the mongoose into mongoose-free islands as well as into the continental United States. The mongoose has not yet reached the North American continent, but in November 1976, mongoose sightings were reported on Dodge Island off the coast of Florida (Nellis et al. 1978). Intensive trapping was conducted in February 1977 and a young female was captured. This followed reports of two other mongooses being killed by local residents in the preceding months. In September 2016 a small Indian mongoose was captured after escaping from a food delivery truck in Orange County, Florida (Florida Fish and Wildlife Conservation Commission, pers. comm.). The origin of this animal was unknown, but was of the same species found in the Caribbean and highlights the potential for inadvertent translocation of invasive species through interstate or international commerce. No other mongooses have been reported from this area, and mongooses have not been reported since on the U.S. mainland.

\section{DAMAGE TO NATIVE FAUNA}

By 1882, 10 years after their introduction, mongooses had spread throughout Jamaica and scientists were noting a sharp decrease in the number of ground-nesting birds, fowl, and reptiles (Lewis 1953). Eight years later, in 1890, initial attempts to reduce mongoose populations were being recommended. Hoagland et al. (1989) found Norway rat ( $R$. norvegicus) densities were indirectly correlated with mongoose densities in Jamaica, whereas mouse (Mus musculus) densities and black rat densities were directly correlated with mongoose densities. Hoagland et al. (1989) go on to suggest that mongooses are ineffective predators of black rats and house mice. Thus, the initial success of mongoose suppression of rodent populations may have been restricted to Norway rats, with little effect on other crop-damaging rodent species. In addition, Lewis (1953) suggested that initial reduction in rat populations also caused rats to become more arboreal and thus relatively safe from mongooses, which are notably poor climbers. Furthermore, the diurnal nature of mongooses versus the 
nocturnal habits of rats likely doomed the introductions for rodent control to failure from the beginning.

Westermann (1953) provides an early summary of the overall effects of introduced fauna, including mongooses, to local flora and fauna throughout the West Indies. Although extinctions attributed directly to mongooses are likely few (Henderson 1992), there are several cases in which population declines have been exacerbated by mongoose introduction. In Puerto Rico, the introduced mongoose has been implicated in the decline of the Puerto Rican parrot (Amazonia vittata; Engeman et al. 2006) and Puerto Rican nightjar (Antrostomus noctitherus; Vilella and Zwank 1993). Mongooses are also known to prey upon the Puerto Rican giant anole (Anolis cuvieri; Schwartz and Henderson 1991), coqui frogs (Eleutherodactylus spp.; Wolcott 1953; Pimentel 1955a,b), and eggs of the Puerto Rican slider (Trachemys stejnegeri stejnegeri; León and Joglar 2005). Wetmore (1927) suggested the mongoose was responsible for the decline of the West Indian nighthawk (Chordeiles gundlachii), short-eared owl (Asio flameus), and two species of quail doves. Espeut (1882) also mentions a decline in a variety of species on Jamaica that he attributed to the mongoose, including snakes, lizards, and crabs, among others. Collar et al. (1992) attributed the decline of the Jamaican petrel (Pterodroma caribbaea) to the mongoose. Also in Jamaica, Lewis et al. (2011) suggested the mongoose was responsible for a reduction in blue-tailed galliwasp (Celestus duquesneyi) and endangered Jamaican iguana (Cyclura collei) populations. The mongoose has been documented damaging nests of the endangered hawksbill turtle (Eretmochelys imbricate), green turtle (Chelonia mydas), and loggerhead sea turtle (Caretta caretta) throughout the U.S. Virgin Islands (Seaman and Randall 1962; Nellis and Small 1983; Coblentz and Coblentz 1985b).

Mongoose introduction has also been suggested as a contributing factor in the decline of the endangered Hispaniolan solenodon (Solenodon paradoxus) in Haiti (Turvey et al. 2008; Thomas 2009). Westermann (1953) stated that the Cuban solenodon (S. cubanus) went extinct around 1910 and suggested mongooses were a significant factor in the solenodon's demise. However, three live Cuban solenodons were captured in 1974-1975 and remnant populations survive in isolated pockets, and the species is now listed as endangered (Soy and Mancina 2008). The impact, or lack thereof, of mongooses on populations of the Cuban solenodon remains unclear. While Westermann (1953) suggested the mongoose was likely responsible for its extermination, Borroto-Páez (2009) suggested domestic dogs and cats were more likely predators of solenodons than mongooses, as the two species are not considered sympatric on Cuba. However, given the adaptability of mongooses to a variety of habitats and evidence of mongoose predation of solenodons in Haiti (Turvey et al. 2008), potential impacts should not be ruled out without further investigation.

Nellis and Everard (1983) discuss the disappearance of various snakes, including Alsophis sancte-crucis, A. ater, and A. rufiventris, from St. Croix, Jamaica, and St. Kitts and Nevis and attribute their demise to mongooses. Damage to domestic poultry is also a concern, although mongooses are more likely to affect subsistence producers rather than commercial poultry operations in the Caribbean. There is anecdotal information on damage to domestic poultry farms (hens, chicks, and eggs) in Hawaii and to sweet potatoes on Okinawa, although published reports are scant. 
Overall, it is estimated that the annual economic impact of mongooses associated with public health, poultry loss, extinctions of various reptiles and amphibians, as well as destruction of native bird species is approximately U.S. \$50 million in the Hawaiian Islands and Puerto Rico alone (Pimentel et al. 2005).

Hawaii has not been excluded from damage by mongoose introduction. The mongoose's impacts on bird populations were noted as early as 1900 (Anonymous 1900). Since its introduction to Hawaii, the mongoose is suspected to have contributed to the decline or extinction of various species of ground-nesting birds, including several species of honeycreepers (Smith and Remington 1996) and the Hawaiian goose (Nesochen [Branta] sandvicensis; Loope et al. 1988; Banko 1982, 1992). Hodges and Nagata (2001) attributed $38 \%$ of known-cause Hawaiian petrel (Petrodoma phaeopygia sandwichensis) mortality to mongooses or domestic cats (Felis catus sylvestri) and $41 \%$ to rats (Rattus spp.). Exclusion of mongooses has also been suggested as a strategy to assist in the recovery of the Hawaiian petrel and Newell's shearwaters (Puffins newelli; Cowan et al. 2014).

The mongoose is not only a contributing factor to the extirpation of some species, but also potentially influences behavior. For example, the bridled quail dove (Geotrygon mystacea), a ground-nesting bird on St. Croix, was thought to be extinct, but Nellis and Everard (1983) suggested it has become an arboreal nester in response to nest predation by mongooses. Also, on St. Croix, the snake Alsophis sancticrucis and two species of lizard (Amevia polops and A. exsul) have declined presumably due to mongoose predation (Nellis 1982). Follow-on effects of mongoose predation may increase populations of various species in trophic cascades, such as in Japan, where Watari et al. (2008) suggested decreases in native predators, such as frogs and lizards, may result in an increase in the abundance of smaller animals. Nellis (1982) also reported an increase in populations of Spaerodactylus and Hemidactylus lizards following mongoose introduction and, presumably as a result of reduced predation by Ameiva spp., an increase in populations of the moth Cactoblastis cactorum, with a resulting estimated $90 \%$ reduction in the cactus Opuntia sp. Townsend (2006) suggested that deforestation may have forced nesting of the threatened golden swallow (Tachycineta euchrysea) in an unsuitable habitat in the Dominican Republic, resulting in nest predation by mongooses, and Allen (1911) describes a reduction in Ameiva lizards on Grenada likely due to mongoose predation.

\section{DISEASE}

Cases of leptospirosis have been reported as a result of mongooses in Puerto Rico (Pimentel 1955a,b), Trinidad, and Grenada (Everard et al. 1976). In addition, leptospirosis is highly prevalent in Hawaii (Alicata and Breaks 1943; Alicata 1958; Minette 1964; Higa and Fujinaka 1976), with dozens of cases reported statewide, some requiring hospitalization (Wong et al. 2012). Cases of Salmonella spp. and Campylobacter spp. have been reported in free-ranging mongooses on Barbados (Rhynd et al. 2014; Matthias and Levett 2002), and although rabies is not present in Hawaii, the mongoose is the primary rabies reservoir on Puerto Rico, Cuba, Grenada, the Dominican Republic, and most likely Haiti (Everard and Everard 1992; Zieger et al. 2014; Berentsen et al. 2015). 
References to rabies in Puerto Rico date back to the 1840 s, prior to the introduction of the mongoose; the first clinically documented case of rabies in mongooses did not occur until 1950 (Tierkel et al. 1952). Seroprevalence in mongooses ranges from $11.7 \%$ up to $40 \%$ on some islands (Zieger et al. 2014; Berentsen et al. 2015), and in Puerto Rico, $70 \%$ of animals testing positive for rabies virus in 2013 were mongooses (Dyer et al. 2014). Rabies virus strains from Grenada (Zieger et al. 2014), Cuba (Nadin-Davis et al. 2006), and Puerto Rico (Nadin-Davis et al. 2008) suggest independent introduction of rabies to different Caribbean islands. No oral rabies vaccination program exists for mongooses, although research into potential oral rabies vaccine baits in the Caribbean has been conducted (Linhart et al. 1993; Creekmore et al. 1994; Berentsen et al. 2014). With large populations of feral dogs and cats, along with no compulsory vaccination for kept domestic animals, risks of rabies transmission between mongooses, domestic animals, and, ultimately, humans remain high.

\section{MANAGEMENT STRATEGIES}

As the perception that mongooses are useful in rodent control waned, they rapidly became a pest species in areas where they have been introduced, and currently the mongoose is listed as one of 100 of the world's worst invasive species (Lowe et al. 2000). Globally, there have been six successful attempts to eradicate mongooses from islands (Barun et al. 2011). All of these islands were less than or at most 115 ha, and populations were eradicated using a variety of methods, including trap/remove and primary or secondary poisoning using rodenticides such as brodifacoum, bromadiolone, or thallium sulfate. Two large-scale ongoing mongoose eradication attempts are being conducted in Japan (Abe 2013). The eradication efforts on 71,200ha Amami-Oshima Island began in 1993, starting with support from local villages and then taken over by the Japanese Ministry of the Environment in 2000. The mongoose eradication effort in northern Okinawa also began in 2000 and encompasses much of the island $(227,130 \mathrm{ha})$. Because these areas have native mammals, control methods are limited to kill traps or live traps requiring euthanasia. Where mongoose populations have been reduced to low levels, native species are recovering (Watari et al. 2008). The challenge remains, however, to develop methods for detecting and controlling mongooses at low densities.

In the Caribbean, early management strategies for mongooses took place in Trinidad through a bounty system which ultimately proved ineffective and costly (Urich 1931). In an effort to protect populations of endangered Puerto Rican parrots as well as human health and safety, limited mongoose control is performed on Puerto Rico (Engeman et al. 2006; Quinn et al. 2006). Rather than large-scale eradication efforts, local control of mongooses has been conducted much more frequently, with live box traps the most common method employed (Barun et al. 2011). Morton (2005) describes trap and removal efforts to protect native iguana (Iguana iguana) nesting sites on St. Lucia. Kill-trapping and acute toxicants such as thallium sulfate, strychnine, sodium monofluoroacetate (Compound 1080), and even ground glass were used historically in the Caribbean (Pimentel 1955b; Everard and Everard 1992; Barun et al. 2011). Currently there is no islandwide control program for mongooses on any islands in the Caribbean. 
The history of organized mongoose control in Hawaii began in 1915 when the Territorial Legislature had appropriated funds for a bounty on the mongoose (Public Health Reports: 1896-1970). The Territorial Fish and Game Commission and individual counties eventually led extermination campaigns that offered cash prizes for the greatest number of mongoose heads (Anonymous 1921). Mongoose bounties eventually proved ineffective and were discarded. Early research into mongoose control included the use of warfarin and zinc phosphide. Although zinc phosphide was found to be effective in killing mongooses, because of its extreme toxicity and risks to domestic livestock, its use was not recommended (Woodworth and Woodside 1953). Subsequent eradication efforts included the use of toxicants such as thallium sulfate (Kridler 1965), and sodium monofluoroacetate injected into chunks of meat that were deposited in crevices near Hawaiian goose nests and throughout sanctuaries (Walker 1974). Later, the anticoagulant diphacinone was also employed (Stone et al. 1995; Smith et al. 2000).

For a wide-ranging carnivore like the mongoose, the efficacy of a control method depends upon the ability of the target species to detect a bait or lure from a distance, follow it to its source, and be attracted enough to it to enter a trap or bait station. The bait or lure must also be evaluated for its stability and longevity: how long does it remain both detectable and attractive? For a toxic bait, the toxicity to the target species must be quantitatively evaluated to ensure that the toxicant is lethal to the majority of individuals in consumable doses. The palatability of the matrix of toxic bait is critical to ensure that the target species will eat enough of the bait to consume a lethal dose of the toxicant. Therefore, each toxic bait product must have its own series of laboratory and field trials to establish its efficacy for a target species (and potential hazard to nontargets), since the active ingredient is not the sole determinant of efficacy (Palmateer and McCann 1976; Keith et al. 1985, 1987; Pitt and Sugihara 2008; Pitt et al. 2015). Field efficacy trials for any method targeting mongooses must be designed on a scale large enough to have a statistically significant sample of mongooses, be replicated in several locations, use multiple independent methods to assess the effects on mongoose abundance within the treatment areas, and be compared with a site where no control methods are used.

In a USDA/Wildlife Services study (Keith et al. 1987), both acute and chronic toxicants, including zinc phosphide, warfarin, and diphacinone, were effective against mongooses in laboratory bioassays. Diphacinone was highly effective in low doses $(0.18 \mathrm{mg} / \mathrm{kg})$, which would minimize hazards to nontarget species. Subsequent field trials at Hawaii Volcanoes National Park and at James Campbell National Wildlife Refuge using diphacinone mixed in raw hamburger at a concentration of $0.00025 \%$ diphacinone, placed in bait stations $125-250 \mathrm{~m}$ apart, killed a high percentage of radio-collared mongooses (Keith et al. 1990). In 1991, a Special Local Need registration was approved for $0.1 \%$ diphacinone concentrate to be mixed into raw hamburger to make a $0.00025 \%$ diphacinone bait to be applied in specially designed bait stations. The design specified a 4-in.-diameter polyvinyl chloride (PVC) pipe in the shape of a T, with entrances in the arms of the T, and bait placed in the supporting arm. This technique proved effective but expensive due to a variety of factors, including bait cost, labor costs associated with bait preparation, bait station construction, logistics involved with ensuring fresh bait over a 12-15day feeding period required to effect control, and installation and maintenance in 
remote areas. Given these restrictions, it was impractical to apply to large conservation areas (Stone et al. 1995), and the registration was allowed to expire.

Recent research on mongoose control has focused on identifying nontoxic baits and lures with a large call distance (distance of effective attraction) to stand out in prey-rich environments (Pitt and Sugihara 2008; Pitt et al. 2015). The instructions for mongoose on the current Ramik ${ }^{\circledR}$ Mini Bars SLN describing the spacing and area over which bait stations should be distributed are based upon the results of Pitt et al. (2015), which determined home range sizes and measured the distances mongooses traveled to investigate novel food baits. No field trials have been conducted to determine the effectiveness of the current bait station instructions at reducing mongoose abundances.

Mongooses were eliminated from within a portion of the Ka'ena Point Natural Area Reserve on Oahu that is separated from the rest of the island by a predator-proof fence. Ramik ${ }^{\circledR}$ Mini Bars containing $0.005 \%$ diphacinone were placed in bait stations in a $25-\mathrm{m}$ grid during construction of the fence, and mongooses were not detected in the area prior to final completion of the fence (Young et al. 2013). Since animals were not radio-collared, and no carcasses were recovered, the exact methods responsible for the apparent eradication are unknown. Of two mongooses that subsequently entered the fenced area, one was caught in a leg-hold trap, and mongoose scat was detected on top of a bait station from which bait take was noted (Young et al. 2013).

A variety of live and kill traps are used for mongoose control in Hawaii. The effectiveness of these methods for controlling mongooses primarily depends on the type of bait used, the spacing between traps, and the area over which they are placed (Keith et al. 1987; Pitt et al. 2015). The skill and experience of the individual trapper in trap placement and setting also affect trapping success. However, while mortality numbers have been recorded in preliminary field trials evaluating efficacy of a variety of trapping methods (Peters et al. 2011), no independent monitoring has determined whether overall mongoose abundance is reduced under current mongoose trapping practices. A variety of multikill, "self-resetting" devices have been developed for use on stoats (Mustela erminea) and rats in New Zealand. Limited data are available on the efficacy of self-resetting traps on mongoose control, but VanderWerf (2015) reported poor success for mongoose control relative to other removal methods. No trials using standardized quantitative methods have been conducted in Hawaii to evaluate the humaneness of self-resetting traps or their effectiveness at reducing local mongoose populations to levels low enough to protect native species. Furthermore, successful use of such devices would require the use of mongoose-specific lures and/or toxicants, neither of which are available. The lures currently used in self-resetting devices come in a variety of food-based scents, but scent lures have been shown to be ineffective for mongooses in Hawaii field trials (Pitt and Sugihara 2008). No extensive evaluation comparing the efficacy of different trap types or trapping strategies on mongoose population densities has been performed.

\section{FUTURE CONTROL METHODS}

Several commercial rodenticide products are registered for use in rodent control in Hawaii, including chlorophacinone $\left(0.005 \%\right.$ a.i.) (Rozol ${ }^{\circledR}$ Pellets; EPA SLN No. 
HI-080002), which is approved for field use against rodents in Hawaiian fruit and nut orchards, sugarcane fields, and selected field seed (corn, soybean) crops (Pitt et al. 2011), as well as a pelleted diphacinone bait (Diphacinone-50; EPA Reg. No. 5622835) for broadcast application in conservation areas. Only one product is registered for use in mongooses: a diphacinone $\left(0.005 \%\right.$ a.i.) rodenticide bait block (Ramik ${ }^{\circledR}$ Minibars; EPA Reg. No. 61282-26) for use in bait stations. However, the attractiveness and palatability of these baits to mongooses has not been thoroughly evaluated in controlled feeding trials. In addition, poor bait acceptance and problems with regurgitation (emesis) have been reported from the field. Other registered rodenticide baits are routinely used in and around industrial, commercial, and agricultural food commodity storage, as well as sorting, processing, and packing structures in Hawaii to control rodent infestation, reduce product and structural damage, and address health and sanitation concerns. Mongooses have been known to visit the rodenticide bait stations, but the operational efficacy of these baits for free-ranging mongooses has been questionable or unknown. Preliminary results from recently completed trials conducted at the USDA National Wildlife Research Center (NWRC) Hawaii Field Station suggest that most commercial wax block or pelleted bait formulations were not palatable to mongooses in free-feeding laboratory trials (USDA/NWRC Hawaii Field Station, unpublished data). One exception was bromethalin, which mongooses readily consumed and to which they succumbed after one day's feeding. Incorporating effective registered rodenticide toxicants into a more palatable matrix may result in more effective bait for mongooses, but would require additional research and evaluation. In addition, mongooses have been shown to be highly susceptible to diphacinone, and formulations with fresh ground beef have proved to be efficacious in free-ranging mongooses (Keith et al. 1990).

A relatively new vertebrate pesticide containing the active ingredient paraaminopropiophenone (PAPP) has shown to be effective in Australia (foxes, feral dogs/cats) and New Zealand (stoats, ferrets, and feral cats) (Fisher et al. 2005; Fisher and O'Connor 2007; Eason et al. 2010). In the United States, PAPP is being investigated as a tool for coyote control (Savarie et al. 1983; Young 2014). PAPP, a methemoglobin forming chemical, reduces the oxygen-carrying capacity of the blood, and, at toxic doses, induces a reported humane death (sleepy, lethargic, unconsciousness within a few hours) (Savarie et al. 1983). The NWRC Hawaii Field Station has informally collaborated with researchers in Japan toward the development of control tools, including microencapsulated PAPP for mongooses. Its lower toxicity to rodents has attracted Japanese interest in testing PAPP against mongooses owing to the presence of two species of native rats in Okinawa and Amami Oshima Islands in the Japanese archipelago. Preliminary results with formulated microencapsulated PAPP delivered in fresh minced chicken look promising for mongoose control.

Sodium nitrite, a commonly used food preservative and ingredient in commercial fertilizers, is another methemoglobemia-inducing chemical that has been investigated as a potential vertebrate pesticide. Australian researchers have conducted studies on the use of microencapsulated sodium nitrite to control invasive wild pigs (Cowled et al. 2008; Lapidge et al. 2012). Hog-Gone ${ }^{\circledR}$ pelleted bait containing sodium nitrite was developed in Australia for invasive wild pig control and is being tested in the United States (Campbell et al. 2012). Witmer (2013) evaluated sodium nitrite as 
a rodenticide, and preliminary results suggest the potential for its use as a toxicant against selected rodent species in the United States. However, preliminary research with mongooses shows some taste aversion at higher concentrations (5\%) when formulated in fresh chicken meat (USDA/NWRC, unpublished data). Additional trials at lower sodium nitrite concentrations are planned.

\section{CONCLUSION}

The introduction of the small Indian mongoose as a biological control agent has resulted in failure and significant ecological damage throughout much, if not all, of its introduced range. Not only have mongooses failed to provide long-term rodent control, but mongooses have caused irreparable damage to native fauna and become reservoirs for diseases such as rabies, leptospirosis, and in some regions possibly Salmonella and Campylobacter. Mongoose suppression of viper populations has met with some success in some Croatia (Barun et al. 2010), but snakes, including vipers, did not make up a significant proportion of the mongoose diet in Japan (Abe et al. 1999).

Effective and efficient population control methods for mongooses have yet to be developed. Trap and lethal removal programs such as those practiced on Okinawa may be successful in significantly reducing populations but are labor- and timeintensive, taking decades of consistent effort, with no guarantee of ultimate success. A variety of toxicants have been evaluated that are effective in laboratory trials, but a bait matrix/delivery system, palatable to mongooses and suitable for field application, has remained elusive. Furthermore, numerous strategies for mechanical removal (i.e., live trap/remove, kill traps) are in use with no standardized measure to evaluate efficacy.

The risk of unintentional mongoose introduction to the North American continent (including currently mongoose-free islands of Hawaii) is highlighted by the early reports of mongooses found in Florida and more recent documentation of this invasive pest species on the island of Kauai. With increased interisland travel among Caribbean Islands and between islands and mainland countries, vigilance must be maintained in inspecting cargo and vessels to prevent further mongoose introductions. Additional intensive research into local and large-scale mongoose management strategies is necessary. Future discussions of introducing biological control agents should carefully consider the long-term consequences before taking any action.

\section{REFERENCES}

Abe, S. 2013. Eradication project of invasive alien mongooses on Amami-oshima Island, Japan. Page 195 in Ministry of the Environment, Government of Japan and International Union for Conservation of Nature (editors). The 1st Asia Parks Congress, November 13-17, 2013. Sendai, Japan.

Abe, S., Y. Hanada, Y. Abe, Y. Takatsuki and H. Nigi. 1999. Food habits of feral mongoose (Herpestes sp.) on Amamioshima, Japan. In G. H. Rodda, Y. Sawai, D. Chiszar and H. Tanaka (eds). Problem Snake Management: The Habut and the Brown Treesnake. Cornell University Press, New York, USA, pp. 372-383.

Alicata, J. E. 1958. A study of leptospirosis in Hawaii. Plantation Health 8:505-512. 
Alicata, J. E. and V. Breaks. 1943. A survey of leptospirosis in Honolulu. Hawaii Medical Journal 2:137-142.

Allen, G. M. 1911. Mammals of the West Indies. Bulletin of the Museum of Comparative. Zoology 54:175-263.

Anonymous. 1900. Destruction of birds by the pestiferous mongoose. The Honolulu Republican July 31, 1900, p. 7, Image 7.

Anonymous. 1921. Cash prizes offered to most successful hunters of mongoose. The Maui News September 9, 1921, p. 9, Image 6.

Asdell, S. A. 1964. Patterns of Mammalian Reproduction, 2nd ed., Cornell University Press, NY, pp. 477-478, 670 pp.

Baldwin, P. H., C. W. Schwartz and E. R. Schwartz. 1952. Life history and economic status of the mongoose in Hawaii. Journal of Mammalogy 33:335-356.

Banko, P. C. 1982. Productivity of wild and captive nene populations. Proceedings of the Hawaii Volcano National Park National Scientific Conference 4:12-32.

Banko, P. C. 1992. Constraints on productivity of wild Nene or Hawaiian Geese Branta sandvicensis. Wildfowl 43:99-106.

Barun, A., I. Budinski and D. Simberloff. 2008. A ticking time-bomb? The small Indian mongoose in Europe. Aliens 26:14-16.

Barun, A., C. C. Hanson, K. J. Campbell and D. Simberloff. 2011. A review of small Indian mongoose management and eradications on islands. In C. R. Veitch, M. N. Clout and D. R. Towns (eds). Island Invasives: Eradication and Management. IUCN, Gland, Switzerland, pp. 17-25.

Barun, A., D. Simberloff and I. Budinski. 2010. Impact of the small Indian mongoose on native amphibians and reptiles of the Adriatic Islands, Croatia. Animal Conservation 13:549-555.

Berentsen, A. R., S. R. Johnson, A. T. Gilbert and K. C. VerCauteren. 2015. Exposure to rabies in small Indian mongooses (Herpestes auropunctatus) from two regions in Puerto Rico. Journal of Wildlife Diseases 51:896-900.

Berentsen, A. R., S. R. Johnson and K. C. VerCauteren. 2014. Bait matrix flavor preference by mongoose (Herpestes auropunctatus) in Puerto Rico: Implications for oral rabies vaccination. Caribbean Journal of Science 48:52-58.

Borroto-Páez, R. 2009. Invasive mammals in Cuba: An overview. Biological Invasions 11:2279-2290.

Campbell, T. A., M. J. Bodenchuk, J. D. Eisemann, S. J. Lapidge, L. Staples and P. Morrow. 2012. Preliminary assessment of the HogHopper ${ }^{\mathrm{TM}}$ for exlucing nontarget wildlife. Proceedings of the Vertebrate Pest Conference 12:333-336.

Coblentz, B. E. and B. A. Coblentz. 1985a. Reproduction and the annual fat cycle of the mongoose on St. John, US Virgin Islands. Journal of Mammalogy 66:560-563.

Coblentz, B. E. and B. A. Coblentz. 1985b. Control of the Indian mongoose (Herpestes auropunctatus) on St. John, US Virgin Islands. Biological Conservation 33:281-288.

Collar, N. J., L. P. Gonzaga, N. Krabbe, A. Madrono Nieto, T. A. Parker III and D. C. Wege. 1992. Threatened Birds of the Americas. ICBP/ICUN Red Data Book, 3rd Edition, part 2. International Council for Bird Preservation, Cambridge.

Corbet, G. B. and J. E. Hill. 1992. Mammals of the Indomalayan Region: A Systematic Review. Oxford University Press, Oxford.

Corn, J. L. and M. J. Conroy. 1998. Estimation of density of mongooses with capture-recapture and distance sampling. Journal of Mammalogy 79:1009-1015.

Cowan, D. P., M. T. Craig, G. C. Spencer, D. G. Ainley and D. Zanjac. 2014. Managment Actions to Prevent the Disappearance of the Hawaiian Petrels (Pterodroma sandwichensis) and Newell's Sheawaters (Puffinus newelli) From West Maui, Hawaii. Hawaii Conservation Conference, Hawaii Convention Center, Honolulu Hawaii, July 15-17, 2014. Pp 121-122. Abstract only. 
Cowled, B. D., P. Eslworth and S. J. Lapidge. 2008. Additional toxins for feral pig (Sus scrofa) control: Identifying and testing Achilles' heels. Wildlife Research 35:651-662.

Creekmore, T. E., S. B. Linhart, J. L. Corn, M. D. Whitney, B. D. Snyder and V. F. Nettles. 1994. Field evaluation of baits and baiting strategies for delivering oral vaccine to mongooses in Antigua, West Indies. Journal of Wildlife Diseases 30:497-505.

Des Vœux, G. W. 1903. My Colonial Service in British Guiana, St Lucia, Trinidad, Fiji, Australia, Newfoundland and Hong Kong: With Interludes vol. 1. J. Murray, London.

Doty, R. E. 1945. Rat control on Hawaiian sugar cane plantations. The Hawaiian Planters' Record 49:71-239.

Duffy, D. C. 2007. Forest bird and non-native mammal inventories at Ka'apahu, Haleakala National Park (HALE), Maui, Hawaii. Technical Report 145, Pacific Cooperative Studies Unit, University of Hawaii at Manoa. 31pp.

Dyer, J. L., P. Yager, L. Orciari, L. Greenberg, R. Wallace, C. A. Hanlon and J. D. Blanton. 2014. Rabies surveillance in the United States during 2013. Journal of the American Veterinary Medical Association 245:1111-1123.

Eason, C. T., E. C. Murphy, S. Hix and D. B. MacMorran. 2010. Development of a new humane toxin for predator control in New Zealand. Integrative Zoology 5:31-36.

Edwards, R. 2006. Habitat selection of the introduced small Indian mongoose (Herpestes javanicus), using radio telemetry and mark-recapture techniques on St. Lucia. $M S$ Thesis, University of Exeter, United Kindgom. 62pp.

Engeman, R., D. Whisson, J. Quinn, F. Cano, P. Quiñones and T. H. White, Jr. 2006. Monitoring invasive mammalian predator populations sharing habitat with critically endangered Puerto Rican parrot Amazonia vittata. Oryx 40:95-102.

Espeut, W. B. 1882. On the Acclimatization of the Indian mungoos in Jamaica. Proceedings of the Zoological Society of London 50:712-714.

Everard C. O. R. and J. D. Everard. 1992. Mongoose rabies in the Caribbean. Annals of the New York Academy of Sciences 653:356-366.

Everard, C. O. R., A. E. Green and J. W. Glosser. 1976. Leptospirosis in Trinidad and Grenada, with special reference to the mongoose. Transactions of the Royal Society of Tropical Medicine and Hygiene 70:57-61.

Fisher, P. and C. O'Connor. 2007. Oral toxicity of $p$-aminopropiophenone to ferrets. Wildlife Research 34:19-24.

Fisher, P. M., C. E. O'Connor and E. C. Murphy. 2005. Acute oral toxicity of p-aminopropiophenone to stoats. New Zealand Journal of Zoology 32:163-169.

Gorman, M. L. 1975. The diet of feral Herpestes auropunctatus (Carnivora: Viverridae) in the Fijian Islands. Journal of Zoology 175:273-278.

Gorman, M. L. 1976. Seasonal changes in the reproductive pattern of feral Herpestes auropunctatus (Carnivora: Viverridae), in the Fijian Islands. Journal of the Zoological Society of London 178:237-246.

Guzmán-Colón, D. and G. J. Roloff. 2014. Small Indian mongoose (Herpestes auropunctatus) population abundance and effects of habitat features on trapping success in protected areas of eastern Puerto Rico. Caribbean Naturalist 19:1-12.

Hays, W. S. T. 1999. Annual dispersal cycle of the small Indian mongoose (Herpestes auropunctatus) (Carnivora: Herpestidae in Hwai'i. Pacific Science 53:252-256.

Hays, S. T. and S. Conant. 2003. Male social activity in the small Indian mongoose Herpestes javanicus. Acta Theriologica 48:485-494.

Hays, S. T. and S. Conant. 2007. Biology and impacts of Pacific Island invasive species. 1. A worldwide review of effects of the small Indian mongoose, Herpestes javanicus (Carnivora: Herpestidae). Pacific Science 61:3-16.

Henderson, R. W. 1992. Consequences of predator introductions and habitat destruction on amphibians and reptiles in the post-Columbus West Indies. Caribbean Journal of Science 28:1-10. 
Higa, H. H. and I. T. Fujinaka. 1976. Prevalence of rodent and mongoose leptospirosis on the Island of Oahu. Public Health Reports 91:171.

Hinton, H. E. and A. M. S. Dunn. 1967. Mongooses: Their Natural History and Behaviour. Oliver and Boyd, Ltd, London. 144pp.

Hoagland D. B., G. R. Horst and C. W. Kilpatrick. 1989. Biogeography and population biology of the mongoose in the West Indies. In C. A. Woods (editor). Biogeography of the West Indies, Past, Present and Future. Sandhill Crane Press, Gainesville, Florida, pp. 611-634.

Hodges, C. S. N. and R. J. Nagata. 2001. Effects of predator control on the survival and breeding success of the endangered Hawaiian Dark-rumped Petrel. Studies in Avian Biology 22:308-318.

Horst, G. R., D. B. Hoagland and C. W. Kilpatrick. 2001. The mongoose in the West Indies: The biogeography and population biology of an introduced species. in C. A. Woods and F. E. Sergile (eds). Biogeography of the West Indies: Patterns and Perspectives. CRC Press, Boca Raton, Florida, USA, pp. 409-424.

Hudson, M. A. 2010. Optimising Monitoring and Control Strategies for Invasive Alien Mammals: The Small Indian Mongoose in St. Lucia. University of Bath, United Kingdom. 51pp.

Johnson, S. R., A. R. Berentsen, C. Ellis, A. Davis and K. C. VerCauteren. 2016. Estimates of small Indian mongoose densities: implications for rabies management. Journal of Wildlife Management 80:37-47.

Kami, H. T. 1964. Foods of the mongoose in the Hamakua District, Hawaii. Zoonoses Research 3:165-170.

Keith, J. O., D. N. Hirata and D. L. Espy. 1985. Control of mongoose predation on endangered Hawaiian birds. Unpublished progress report. USFWS Denver Wildlife Research Center, $37 \mathrm{pp}$.

Keith, J. O., D. N. Hirata and D. L. Espy. 1987. Control of mongoose predation on endangered Hawaiian birds. Unpublished progress report, 1986. USDA APHIS Denver Wildlife Research Center. 24pp.

Keith, J. A., D. N. Hirata D. L. Espy, S. Greiner and D. Griffin. 1990. Field evaluation of $0.00025 \%$ diphacinone bait for mongoose control in Hawaii. Unpublished final report USDA/APHIS/Denver Wildlife Research Center, 49pp.

Kridler, E. 1965. Experimental poisoning of the Hawaiian mongoose with thallium sulfate. U.S. Fish and Wildlife Service, Honolulu, Hawaii. Unpublished report. 12 pp.

Lapidge, S., J. Wishart, L. Staples, K. Fagerstone, T. Cambell and J. Eisemann. 2012. Development of a feral swine toxic bait $\left(\right.$ Hog-Gone $\left.{ }^{\circledR}\right)$ and bait hopper (Hog-Hopper $\left.{ }^{\mathrm{TM}}\right)$ in Australia and the USA. Proceedings of the Wildlife Damage Management Conference 14:19-24.

Lekagul, B. and J.A. McNeely. 1977. Mammals of Thailand. Association for the Conservation of Wildlife, Bangkok, Thailand.

León, A. and R. L. Joglar. 2005. La jicotea Puertorriqueña. In: R. L. Joglar (editor). Editorial Instituto de Cultura Puertorriqueña. Biodiversidad de Puerto Rico: Vertebrados Terrestres y Ecosistemas. Serie de Historia Natural, San Juan, Puerto Rico, 181-190.

Lewis, C. B. 1953. Rats and the mongoose in Jamaica. Oryx 3:170-172.

Lewis, D. S., R. van Veen and B. S. Wilson. 2011. Conservation implications of small Indian mongoose (Herpestes auropunctatus) predation in a hotspot within a hotspot: The Hellshire Hills, Jamaica. Biological Invasions 13:25-33.

Linhart, S. B., T. E. Creekmore, J. L. Corn, M. D. Whitney, B. D. Snyder and V. F. Nettles. 1993. Evaluation of baits for oral rabies vaccination of mongooses: Pilot field trials in Antigua, West Indies. Journal of Wildlife Diseases 29:290-294.

Loope, L. L., O. Hamann and C. P. Stone. 1988. Comparative conservation biology of oceanic archipelagoes: Hawaii and the Galápagos. BioScience 38:272-282.

Lowe S., M. Browne, S. Boudjelas and M. De Poorter. 2000. 100 of the World's Worst Invasive Alien Species A Selection from the Global Invasive Species Database. Published 
by The Invasive Species Specialist Group (ISSG) a specialist group of the Species Survival Commission (SSC) of the World Conservation Union (IUCN), Invasive Species Specialist Group, Auckland, New Zealand, 12pp.

Lunan, J. 1814. Hortus Jamaicensis, Or a Botanical Description (according to the Linnean System) and an Account of the Virtues, \&c. of Its Indigenous Plants Hitherto Known, as Also of the Most Useful Exotics: Compliled from the Best Authorities, and Alphabetically Arranged, in Two Volumes vol. 2. St. Jago de la Vega Gazette, Jamaica.

Matthias, M. A. and P. N. Levett. 2002. Leptospiral carriage by mice and mongooses on the island of Barbados. The West Indian Medical Journal 51:10-13.

Menard, T., K. Gundersen and J. Chapman. 2013. Kaua'i mongoose: Can we eradicate them? Hawaii Conservation Conference, July 16-18, 2013, Hawaii Convention Center, p. 30, Abstract only.

Minette, Henri P. 1964. Leptospirosis in rodents and mongooses on the island of Hawaii. The American Journal of Tropical Medicine and Hygiene 13:826-832.

Morton, M. N. 2005. Mongoose trapping at Louvet Estate iguana nesting site 2005. Unpublished report. St. Lucia Forestry Department and Durrell Wildlife Conservation Trust. 5pp.

Myers, J. G. 1931. The present position of the mongoose in the West Indies. Tropical Agriculture 8:94-95.

Nadin-Davis S. A., G. Torres, M. de Los Angeles Ribas, M. Guzman, R. Cruz de La Paz, M. Morales and A. I. Wandeler. 2006. A molecular epidemiological study of rabies in Cuba. Epidemiology and Infection 134:1313-1324.

Nadin-Davis S. A., J. Velez, C. Malaga and A. I. Wandeler. 2008. A molecular epidemiological study of rabies in Puerto Rico. Virus Research 131:8-15.

Nellis, D. W. 1982. Mongoose influence in the ecology of islands. Transactions of the International Congress of Game Biologists 14:311-314.

Nellis, D. W. 1989. Herpestes auropunctatus. Mammalian Species 342:1-6.

Nellis, D. W., N. F. Eichholz, T. W. Regan and C. Feinstein. 1978. Mongoose in Florida. Wildlife Society Bulletin 6:249-250.

Nellis, D. W. and C. O. R. Everard. 1983. The biology of the mongoose in the Caribbean. In P. W. Hummenlinck and L. J. Van der Steed (eds). Studies on the Fauna of Curacao and Other Caribbean Islands, Foundation for the Scientific Research in Surinam and the Netherlands Antilles, Utrecht, the Netherlands, pp. 1-162.

Nellis, D. W. and V. Small. 1983. Mongoose predation on sea turtle eggs and nests. Biotropica 15:159-160.

Palmeeter, S. D. and J. A. McCann. 1976. Relationship of acceptance and mortality of anticoagulant baits to rats. Bulletin of Environmental Contamination and Toxicology 15:750-755.

Peacock, D. and K. Abbott. 2010. The mongoose in Australia: Failed introduction of a biological control agent. Australian Journal of Zoology 58:205-227.

Pearson, O. P. and P. H. Baldwin. 1953. Reproduction and age structure of a mongoose population in Hawaii. Journal of Mammalogy 34:436-447.

Peters, D., L. Wilson, S. Mosher, J. Rohrer, J. Hanley, A. Nadig, M. Silbernagle, et al. 2011. Small Indian mongoose-management and eradication using DOC 250 kill traps, first lessons from Hawaii. In C. R. Veitch, M. N. Clout and D. R. Towns (eds). Island Invasives: Eradication and Management. IUCN, Gland, Switzerland, pp. 225-227.

Pimentel, D. 1955a. Biology of the Indian mongoose in Puerto Rico. Journal of Mammalogy 36:62-68.

Pimentel, D. 1955b. The control of the mongoose in Puerto Rico. Americal Journal of Tropical Medicine and Hygiende 4:147-151.

Pimentel, D., R. Zuniga and D. Morrison. 2005. Update on the environmental and econimic costs associated with alein-invasive species in the United States. Ecological Economics 52:273-288. 
Pitt, W. C., L. C. Criscoll and R. T. Sugihara. 2011. Efficacy of rodenticide baits for the control of three invasive rodent species in Hawaii. Archives of Environmental Contamination and Toxicology 60:533-542.

Pitt, W. C. and R. T. Sugihara. 2008. Evaluation of selected natural and artificial attractants, lures, and bait substrates for attracting small Indian mongooses (Herpestes auropunctatus) to traps and activity stations in Hawaii.

Pitt, W. C., R. T. Sugihara and A. R. Berentsen. 2015. Effect of travel distance, home range, and bait on the management of small Indian mongooses, Herpestes auropunctatus. Biological Invasions 17:1743-1759.

Public Health Reports (1896-1970), vol 30, No. 38, Sept 17, 1915, p. 2834.

Quinn, J. H. and D. A. Whisson. 2005. The effects of anthropogenic food on the spatial behaviour of small Indian mongooses (Herpestes javanicus) in a subtropical rainforest. Journal Zoology 267:339-350.

Quinn, J. H., D. A. Whisson and F. Cano. 2006. Managing the small Indian mongoose (Herpestes javanicus) in the midst of human recreation: What is the optimal approach? Proceedings of the Vertebrate Pest Conference 22:393-398.

Rhynd, K. J. R., P. A. Leighton, D. A. Elcock, P. J. Whitehall, A. Rycroft and S. K. Macgregor. 2014. Prevalence of Salmonella spp. and thermophilic Campylobacter spp. in the small Asian mongoose (Herpestes javanicus) in Barbados, West Indies. Journal of Zoo and Wildlife Medicine 45:911-914.

Savarie, P. J., H. Ping Pan, D. J. Hayes, J. D. Roberts, G. L. Dasch, R. Felton and E. W. Schafer, Jr. 1983. Comparative acute oral toxicity of para-aminopropiophenone. Bulletin of Environmental Contamination and Toxicology 30:122-126.

Schwartz, A. and R. W. Henderson. 1991. Amphibians and Reptiles of the West Indies: Descriptions, Distributions, and Natural History. Univ. Florida Press, Gainesville, $720 \mathrm{p}$.

Seaman, G. A. and J. E. Randall. 1962. The mongoose as a predator in the Virgin Islands. Journal of Mammalogy 43:544-546.

Shekhar, K. S. 2003. The status of mongooses in central India. Small Carnivore Conservation 29:22-23.

Simberloff, D., T. Dayan, C. Jones and G. Ogura. 2000. Character displacement and release in the small Indian mongoose, Herpestes javanicus. Ecology 81:2086-2099.

Smith, D. G., J. T. Polhemus and E. A. VanderWerf. 2000. Efficacy of fish-flavored diphacinone bait blocks for controlling small Indian mongoose (Herpestes auropunctatus) populations in Hawai'i. 'Elepaio 60:47-51.

Smith, H. R. and C. L. Remington. 1996. Food specificity in interspecies competition. BioScience 46:436-447.

Soy, J. and C. A. Mancina. 2008. Solenodon cubanus. The IUCN Red List of Threatened Species. Version 2015.2. http://dx.doi.org/10.2305/IUCN.UK.2008.RLTS.T20320A918 5957.en. Accessed July 22, 2015.

Spencer, H. J. 1950. Mongoose control research project, Virgin Islands, USA, OctoberNovember 1950. United States Fish and Wildlife Service, unpublished report. 7pp.

Stone, C. P., M. Dusek and M. Aeder. 1995. Use of an anticoagulant to control mongooses in Nene breeding habitat. 'Elepaio 54:73-78.

Stone, C. P., L. W. Pratt and J. M. Yoshioka. 1994. Hawai'i's plants and animals: biolgocial sketches of Hawaii Volcanoes National Park. University of Hawaii Press, Honolulu, Hawaii, USA.

Thomas, C. 2009. Saving a venomous ghost. Science 325:531.

Tierkel, E. S., G. Arbona, A. Rivera and A. de Juan. 1952. Mongoose rabies in Puerto Rico. Public Health Reports 67:274-278.

Tomich, P. Q. 1986. Mammals in Hawaii, 2nd ed. Bishop Museum Special Publication 76. Bishop Museum Press, Honolulu, Hawaii, 375pp. 
Townsend, J. 2006. Predation of a golden swallow (Tachycineta euchrysea) nest by the Indian mongoose (Herpestes javanicus) in the Sierra de Bahoruco, Dominican Republic. Journal of Caribbean Ornithology 19:108-109.

Turvey, S. T., H. M. R. Meredith and R. P. Scofield. 2008. Continued survival of Hispaniolan solenodon Solenodon paradoxus in Haiti. Oryx 42:611-614.

Urich, R. W. 1914. The mongoose in Trinidad and methods of destroying it. Board of Agriculture Trinidad and Tobago Circular 12:5-12.

Urich, R. W. 1931. The mongoose in Trinidad. Tropical Agriculture 8:95-97.

VanderWerf, E. 2015. Performance of Goodnature Automated Predator Traps to Protect Forest Bird and Sea Bird Nests on O'ahu. Hawaii Conservation Conference, August 3-6, 2015, University of Hawaii at Hilo, p. 97. Abstract only.

Veron, G., M-L. Patou, G. Pothet, D. Simberloff and A. P. Jennings. 2007. Systematic status and biogeography of the Javan and small Indian mongooses (Herpestidae, Carnivora). Zoologica Scripta 36:1-10.

Vilella, F. J. 1998. Biology of the mongoose (Herpestes javanicus) in a rain forest of Puerto Rico. Biotropica 30:120-125.

Vilella, F. J. and P. J. Zwank. 1993. Ecology of the small Indian mongoose in a coastal dry forest of Puerto Rico where sympatric with the Puerto Rican nightjar. Caribbean Journal of Science 29:24-29.

Walker, R. L. 1974. 1972 report of Nene restoration program. State Department of Land and Natural Resources. Elepaio 34:123-142.

Watari, Y., S. Nishijima, M. Fukasawa, F. Yamada, S. Abe and T. Miyashita. 2008. Evaluating the "recovery level" of endangered species without priori information before alien invasion. Ecology and Evolution 3:4711-4721.

Westermann, J. H. 1953. Nature preservation in the Caribbean. A review of literature on the destruction and preservation of flora and fauna in the Caribbean area. Foundation for Scientific Research in Surinam and the Netherlands Antilles, Utrecht, the Netherlands. 107pp.

Wetmore, A. 1927. The birds of Porto Rico and Virgin Islands. New York Academy of Sciences, Scientific Survey of Porto Rico and the Virgin Islands 9(3 and 4):254-571.

Williams, C. B. 1918. The food of the mongoose in Trinidad. Bulletin of the Department of Agriculture of Trinidad and Tobago 17:167-186.

Witmer, G. 2013. A preliminary evaluation of sodium nitrite as a rodenticide. Unpublished final report, QA-1752. USDA/APHIS/WS/NWRC, 14pp.

Wolcott, G. N. 1953. Food of the mongoose Heprestes javanicus auropunctatus in St. Croix and Puerto Rico. Journal of Agriculture of the University of Puerto Rico 37:241-247.

Wong, M., A. R. Katz, D. Li and B. A. Wilcox. 2012. Leptospira infection prevalence in small mammal host populations on three Hawaiian islands. The American Journal of Tropical Medicine and Hygiene 87:337-341.

Woodworth, J. R. and D. H. Woodside. 1953. Mongoose poison experiment. Territory of Hawaii Division of Fish and Game, unpublished report. 18pp.

Yamada, F. 2002. Impacts and control of introduced small Indian mongoose on Amami Island, Japan. In C. R. Veitch and M. N. Clout (eds). Turning the Tide: The Eradication of Invasive Species. IUCN SSC Invasive Species Specialist Group, IUCN, Gland, Switzerland and Cambridge, UK, pp. 389-392.

Young, J. 2014. Efficacy of para-aminopropiophenone formulation with the M-44 for coyote control. QA-2049. 15pp.

Young, L. C., E. A. VanderWerf, M. T. Lohr, C. J. Miller, A. J. Titmus, D. Peters and L. Wilson. 2013. Multi-species predator eradication within a predator-proof fence at Ka'ena Point, Hawai'i. Biological Invasions 15:2627-2638.

Zieger, U., D. A. Marson, R. Sharma, A. Chikweto, K. Tiwari, M. Sayyid, B. Lousin et al. 2014. The phylogeography of rabies in Grenada, West Indies, and implications for control. PLOS Neglected Tropical Diseases 8(10):e3251. 